Relations industrielles

Industrial Relations

\title{
Cancer and the Worker, New-York The New York Academy of Sciences, 1977.
}

\section{Ray Sentes}

Volume 33, numéro 3, 1978

URI : https://id.erudit.org/iderudit/028903ar

DOI : https://doi.org/10.7202/028903ar

Aller au sommaire du numéro

Éditeur(s)

Département des relations industrielles de l'Université Laval

ISSN

0034-379X (imprimé)

1703-8138 (numérique)

Découvrir la revue

Citer ce compte rendu

Sentes, R. (1978). Compte rendu de [Cancer and the Worker, New-York The New York Academy of Sciences, 1977.] Relations industrielles / Industrial Relations,

33(3), 573-574. https://doi.org/10.7202/028903ar

Tous droits réservés @ C Département des relations industrielles de l'Universite Laval, 1978
Ce document est protégé par la loi sur le droit d'auteur. L’utilisation des services d'Érudit (y compris la reproduction) est assujettie à sa politique d'utilisation que vous pouvez consulter en ligne.

https://apropos.erudit.org/fr/usagers/politique-dutilisation/ 
seignement supérieur, l'insatisfaction locale à l'égard de l'influence réelle du personnel enseignant dans la prise de décisions et les tensions préexistantes entre le personnel enseignant et l'administration ont tous contribué de façon significative. Il est intéressant de noter que devant une certaine compétition intersyndicale, le personnel a toujours voté en faveur de la syndicalisation. De plus, les liens traditionnels ont joué un rôle majeur dans le choix du syndicat.

L'étude des neuf cas est un peu fastidieuse et répétitive, mais cela est inhérent à l'approche choisie. Elle nous permet tout de même d'isoler le facteur le plus déterminant sur le mouvement de syndicalisation en milieu professoral ; soit les changements organisationnels particulièrement au niveau de l'État. La syndicalisation est perçue par plusieurs professeurs comme un moyen de défense contre l'intrusion toujours grandissante de l'État sur leurs conditions de travail. Elle nous permet aussi de comprendre que la syndicalisation de l'Université Rutgers était un geste très conservateur qui fut d'ailleurs appuyé par les autorités de l'Université. Lors d'une autre étude, Ladd et Lipset ont jugé que Rutgers fut l'une des premières universités importantes à accorder une reconnaissance syndicale. Les auteurs du volume nous révèlent que deux craintes majeures sont à l'origine de cette syndicalisation; 1) la syndicalisation massive des collèges régionaux et la crainte que Rutgers soit intégré au sein d'une seule unité de négociation pour tout le système et 2) la crainte par le Bureau des gouverneurs de perdre encore plus d'autonomie face aux autorités de l'État.

Dans l'ensemble, le volume est d'intérêt historique.

Trefflé LACOMBE

Université d'Ottawa

Cancer and the Worker, New-York The New York Academy of Sciences, 1977

Hundreds of thousands of Canadian workers will go to their jobs tomorrow not knowing what dangers they face. Many of them will be exposed to cancer causing agents or processes. Few of them will be told of that fact. It isn't that governments, professionals and employers don't know about cancer in the work place. Its just that they rarely bother to tell workers.

This New York Academy of Sciences publication embodies a different approach. Based on a U.S. scientific conference on Occupational Carcinogins held in March, 1975 , its starting point is that «All workers have the right to know, especially when the subject is cancer. Scientists, and industry and government officials have the moral responsibility to share with workers whatever knowledge they have, even if it is limited at this time. This book is a step in that direction. It is a tool for seeking a safer workplace. Use it.» The book is divided into four parts.

Part I deals with subjects such as: What is cancer? What causes it? Is cancer reversible? How much exposure to a carcinogin does it take to cause cancer? Part II discusses three broad groups of substances which cause occupational cancer: chemicals, metal, dusts and fibers.

This information has been taken directly from the scientific papers and rewritten for workers. Chemicals including: vinyl chloride, benezene, cutting and lubricating oils are discussed and labelled as cancer causing. Nickel, arsenic and chromates are metals which cause cancer. Asbestos, radioactive particles, and some wood dusts are proven carcinogins. Fibrous glass, commonly used as an asbestos substitute is placed in a 'caution' group. "...scientists stress that until more is known, exposure to glass fibers should be kept to a minimum through engineering controls and good work practices.» Also, in part II the effects of smoking and the danger of industrial cancer reaching into workers' homes and communities is pointed out.

Part III is concerned with ways to prevent occupational cancer. Efforts by the Occupational Safety and Health Administration (OSHA) and the National Institute for Occupational Safety and Health (NIOSH) in controlling cancer hazards are outlined. The basic principles used by NIOSH deserve attention. They are:

- Any substance that definitely causes tumors in animals should be considered 
carcinogenic and a potential cancer hazard in man.

It doesn't matter whether the substance causes benign tumors or malignant ones, since a benign tumor often turns cancerous.

- There is no known way to determine a safe level of exposure to any substance known to cause cancer in animals.

One hopes that the new Canadian Centre of Occupational Health and Safety will quickly adopt these principles. Our workers would thus be able to feel confident that Canadian authorities, too, are determined to prevent cancer in the workplace.

Finally, the whole question of cancer is placed within the political and economic structure of our society where it properly belongs. "The real issue in occupational cancer is not so much if we can prevent it as to whether we are willing to prevent it. Occupational cancer is a social disease, a disease whose causes and control are deeply rooted in the technology and economy of our society. Prevention of cancer is largely an attainable goal, but it requires the coordinated effort of all parts of society: government, the scientific community, industry, labor, and an informed public.» Although many examples given are from the U.S. the issues raised are international Cancer and the Worker must be read by workers. Their lives may depend on it.

\section{Ray SENTES}

International Association of Heat and Frost Insulators \& Asbestos Workers

Les politiques concernant la vie au travail, Paris, OCDE, 1977, 84 pp.

Cette publication récente de l'OCDE explore les problèmes posés par la qualité de la vie au travail, décrit les mesures déjà prises à ce sujet par les pays membres, énonce les principes de ce qui pourrait être une politique d'ensemble et discute des moyens d'action les plus appropriés. Une annexe consigne le travail effectué par deux spécialistes dans le but de clarifier les concepts utiles à l'étude de la vie au travail, d'identifier les divers composants de la question et d'établir un cadre de référence cohérent.
En matière de politiques futures et de mesures souhaitables, ce rapport de l'OCDE déçoit quelque peu. Confiné au niveau des généralités en raison de la position de l'OCDE face. aux pays membres et de la diversité des options et des actions de ces derniers en matière de vie au travail, il se borne à l'énoncé de suggestions peu compromettantes: déclaration de principe des gouvernements en faveur de l'amélioration de la vie au travail; encouragement aux mesures spontanément prises par les employeurs et les syndicats; encouragement à l'éducation et à la recherche; octroi de subventions ou de stimulants fiscaux aux entreprises qui procèdent aux améliorations nécessaires.

Par contre, ce rapport présente un intérêt certain à un double point de vue: il résume les mesures déjà prises dans les pays membres et donne ainsi un aperçu des nombreuses possibilités d'action en ce domaine; il fait état des différents obstacles et des nombreuses variables à considérer au moment d'entreprendre des actions en vue d'améliorer la qualité de la vie au travail.

L'annexe, plus considérable que le rapport, suscite aussi plus d'intérêt. Sous la responsabilité des seuls auteurs, la discussion est plus approfondie. L'énoncé du problème, les dimensions retenues et les questions fondamentales de politique forment un ensemble bien articulé avec lequel on est pas toujours d'accord mais qui offre l'avantage de situer les uns par rapport aux autres et d'une manière cohérente les différents éléments du problème. Quatre aménagements principaux visant à l'amélioration de la vie professionnelle y sont examinés: participation des travailleurs à la gestion, «humanisation» de l'organisation du travail, amélioration de l'environnement physique et du contrôle des risques, et reconnaissance accrue des conséquences de la vie de travail sur la vie de non-travail. Les considérations du patronat, des syndicats, des travailleurs et des experts concernant chacun de ses aménagements principaux sont présentées.

Peu volumineuse (84 pages) et de lecture agréable, cette publication constitue une excellente occasion pour un non spécialiste de s'initier aux politiques concernant la vie au travail, de prendre connaissance des 